\title{
Influence of paleodislocation intensity and modern movements on the stressed state of massif
}

\author{
Dmytro Pymonenko ${ }^{1, *}$ \\ ${ }^{1}$ Institute of Geotechnical Mechanics named by N. Poljakov of National Academy of Sciences of \\ Ukraine, 49005, Dnipro, Simferopolska Str., 2a, Ukraine.
}

\begin{abstract}
To study the nature of the forces determining the stress state of the massif, the results of experimental studies of determining numerical values and spatial orientation of the main components of the active stress field using the local hydraulic fracturing method in coal mines of Central Region of Donbas are compared with maps characterizing the intensity of the distribution of paleo-and modern tectonic processes in the area of Donbas. Statistical relationships between indicators characterizing the stress state and the physicomechanical properties of rock are established. The results of performed studies show that the stress fields measured under the conditions of the mines of the Central Region of Donbas are mainly due to modern movements, but the paleological disturbances of tectonic blocks with disjunctive dislocations have a significant effect on the change in the stress state of the massif.
\end{abstract}

\section{Introduction}

The geomechanical state of rocks is influenced mainly by the stress-strain state, reservoirand-mechanical properties of the medium. Theoretical and experimental studies of the parameters of the state of rock and the physical processes occurring during the underground mining of minerals are given in papers [1-5]. As a result of the research performed, initial and theoretical data as to the natural stress state of the upper layers of the earth's crust were obtained, the main forms of rock pressure manifestation in underground mining were classified, the reservoir-and-mechanical properties of the rock were studied.

Currently, the views on the nature of stresses in the massif are controversial [6]. Ideas about the numerical values and the nature of distribution of the main stresses in the rock mass, the gas pressure and its interaction with the fractured-pore structure of the reservoirs, the effect of gas saturation on the mechanical properties of rocks under the differentcomponent stress state have ambiguous character. Diversity of views, ambiguity of interpretation of experimental data, difference in conceptual ideas about the real mechanical state of the rock mass indicate the complexity and lack of knowledge of the factors forming it, one of which is the intensity of paleodisturbance and modern movements. Paleodisturbance characterizes the fragmentation of individual sections, and modern

*Corresponding author: kvalitet@i.ua 
movements - their behavior during the development of coal seams. The purpose of the work is to study the influence of paleo- and modern tectonic processes on the stress state of a rock mass.

\section{Methods}

One of the main factors responsible for the mechanical state of rocks is the initial (natural) stresses of these rocks, which are characterized by numerical values and spatial orientation of the main components of the active stress field. The formation of a natural stress field is the result of paleo-and modern geodynamic processes arising from the movement of lithospheric plates. And since the plates are in constant motion, the array has a certain stress state at each moment of time. An analysis of the geodynamic settings showed that during the Phanerozoic on the southern margin of the East European Platform (EEP), the direction and nature of the operated forces remained, but their intensity periodically changed. The repetition of similar tectonic plans led to the fact that the zones of regional faults developed along very close structural directions, which explains the constancy of the directions of extension of some fault systems. Changes in the state of the lithosphere affect the redistribution of the stress state and lead to the formation of a new system of disturbances. Changes in the directions of the acting forces are associated with the movements of the EEP along the meridian and convergent processes.

This paper examines the nature of the forces that determine the stress field, the correspondence of their proposed model and the effect of tectonics on the magnitude of the main components of the modern stress field. The choice of objects of study within the same structure will make it possible to exclude the influence of regional tectonic and lithologicfacial conditions and determine the influence of local paleotectonic disturbance.

To study the nature of the forces determining the stress state of the massif, the results of [3] experimental studies of determining numerical values (total number of definitions 520) and spatial orientation of the main components of the active stress field using the local hydraulic fracturing method in coal mines Central Region of Donbas (CR) are compared with maps characterizing the intensity of the distribution of paleo-and modern tectonic processes in the area of Donbas. The type, amplitude and extension of large-amplitude disturbances reflect the magnitude and direction of the ancient forces, the low-amplitude disturbances reflect the magnitude and direction of the younger ones forces.

The main geological structure of the Central Region is the Horlivka anticline. Horlivka anticline in sedimentation mass is expressed by a simple narrow fold with $\left(60-80^{\circ}\right)$ angles of incidence, which can be traced in azimuth $110^{\circ}\left(290^{\circ}\right)$. The axis of the Horlivka anticline, according to the [7], is located souther of the Central Donbas deep fault, the axis is associated spatially and genetically with it. The axis from the west is bounded by a transregional submeridional fault, traced hundreds of kilometers to the south and north of the Donbas; within the structure, two diagonal faults of the north-east strike are also located, located to the southeast of the Horlivka-Kalininsk and Yunkomivsk-Bulavinsk upthrow-shear. The anticline is broken by these faults into tectonic blocks of various sizes and shapes. As a result of the periodic activation of movements along the faults during the Phanerozoic, an individual tectonics for each block was formed. The number and type of deformations over the block area vary widely, but on average they reflect the intensity and prevailing directions of the paleo-forces acting on it.

Based on the analysis of the parameters of folded and rupture faults, as well as taking into account the morphology of the latter, four tectonic blocks were identified on the wings of the Horlivka anticline. The studied mines are located: in the 1-st (Yu.O. Haharin Mine), 3-rd (K.A. Rumiantsev Mine) and the 4-th (A.I. Haiovyi Mine) tectonic blocks, which are characterized approximately by the same lithofacial conditions, as well as by the grade 
composition of coal seams, natural gas content, but differ in the degree and nature of tectonic dislocation.

The first block, located on the southern wing of the Horlivka anticline north-west of the Horlivka overthrust, is the most disturbed. The Yu.O. Haharin Mine developed 18 seams, the total number of low-amplitude disturbances complicating coal seams is 158; their predominant number is represented by uplifts of sublatitudinal strike with a steep incidence of displacer planes to the south-east; the average value of low-amplitude disturbance 13.1.

At the K.A. Rumiantsev Mine located on the north wing of the Horlivka anticline, developed 20 coal seams, the average intensity of low-amplitude disturbance is 4.7 . The total number of disturbances at the mine is 50 . Among the ruptured dislocations, the thrust of the sublatitudinal strike prevails, in which the planes of displacers fall to the north-west.

The A.I. Haiovyi Mine located in the hanging wing of the Horlivka overthrust, is developed 16 coal seams. The magnitude of low-amplitude disturbance is on average 3.07. The total number of disturbances at the mine is 23 ; at the same time, in contrast to the mines considered above, the disturbances are dominated by changes in power with a strike azimuth of $290-330^{\circ}$, which reflects the small intensity acting in this block of paleostress.

To quantify the paleodislocation of mines, non-dimensional indicator is calculating, which is a ratio of the total number of disturbances to the number of banks $K_{t}$. To assess the intensity of modern movements, we are using the index given in article [8]: the range of vertical movements $(\Sigma A, \mathrm{~mm} /$ year), non-dimensional indicator the differentiation of modern movements $N_{c}$ and the intensity of modern movements $\left(I_{c}=\Sigma A / N_{c}, \mathrm{~mm} / \mathrm{year}\right)$.

The calculated data (see Table 1) show that the selected objects differ in the degree of dislocation (in the more deformed blocks, coal seams are more disturbed) and in the type of disturbances.

Table 1. Parameters of the main components of the stress field, paleo-and modern location in the mines of the Central Region of Donbas.

\begin{tabular}{|c|c|c|c|c|c|c|c|c|}
\hline \multirow{2}{*}{ Mine } & \multirow{2}{*}{$\begin{array}{c}K_{t}, \\
\text { non- } \\
\text { dim. } \\
\text { (non- } \\
\text { dimen- } \\
\text { sional) }\end{array}$} & \multicolumn{3}{|c|}{$\begin{array}{c}\text { Types of low-amplitude } \\
\text { faults, } \\
\text { amount } / \%\end{array}$} & \multirow{2}{*}{$\begin{array}{c}\text { Range } \\
\text { of } \\
\text { vertical } \\
\text { move- } \\
\text { ments } \\
\sum A, \\
\text { mm/ } \\
\text { year }\end{array}$} & \multicolumn{3}{|c|}{$\begin{array}{l}\text { Main components } \\
\text { of the stress field } \\
\text { (on the horizon of } \\
830 \mathrm{~m} \text { ), MPa }\end{array}$} \\
\hline & & $\begin{array}{c}\text { Over- } \\
\text { laps }\end{array}$ & $\begin{array}{l}\text { down- } \\
\text { throws }\end{array}$ & others & & $\sigma_{1}$ & $\sigma_{2}$ & $\sigma_{3}$ \\
\hline $\begin{array}{l}\text { Yu.O. Haharin } \\
\text { Mine }\end{array}$ & 8.6 & $85 / 54$ & $20 / 13$ & $40 / 25$ & 2.6 & 41.4 & 20.0 & 16.0 \\
\hline $\begin{array}{l}\text { K.A. Rumiantsev } \\
\text { Mine }\end{array}$ & 2.5 & $20 / 40$ & $2 / 3$ & $25 / 49$ & 6.0 & 47.8 & 22.8 & 18.8 \\
\hline $\begin{array}{l}\text { A.I. Haiovyi } \\
\text { Mine }\end{array}$ & 1.1 & $2 / 7$ & $3 / 14$ & $16 / 70$ & 6.6 & 49.0 & 21.0 & 15.4 \\
\hline
\end{tabular}

Reconstruction of the main directions of the paleostress field within the first and third blocks at which these dislocations arose suggests that these discontinuities were formed as a result of the maximum horizontal compressive forces directed along the Horlivka anticline axis on the south wing from south-east to north-west (azimuth $280-300^{\circ}$ ) in the north from the north-west to the south-east (azimuth $100-110^{\circ}$ ), the axis of minimum stress is directed perpendicular to the hinge of the anticline, the axis of the intermediate subvertically. Judging by the intensity of deployment, their size on the north wing is less than on the south.

The intensity of modern tectonic movements in the Central Region differs from the 
Phanerozoic as follows: in the A.I. Haiovyi Mine and K.A. Rumiantsev Mine their values are approximately equal $(6.0-6.6)$, at the mine to Yu.O. Haharin almost 2.5 times less.

Analysis of the experimental data shows that the rocks that contain the worked out coal seams are in a multi-component stress field. The maximum component of the stress tensor is oriented close to the strike of rocks $\left(100-110^{\circ}\right)$; the smaller horizontal component $\sigma_{3}$ is orthogonal $\sigma_{1}$ and is oriented across the strike of rocks; the vertical component, which occupies an intermediate position, is oriented in the sub-vertical (relative to the earth's surface) direction with a slight (up to $10^{\circ}$ ) inclination to the line of incidence of the rocks.

Comparison of measurements of components of the stress field components on the horizon of $830 \mathrm{~m}$ with data characterizing the intensity of ancient and modern tectonics show that the maximum horizontal component of the stress field $\sigma_{1}$, is greater in mines where the paleotectonic dislocation is less and the intensity of modern movements is higher. Consequently, the measured stress fields in the studied arrays are due to modern movements, but the paleodisturbance of tectonic blocks by discontinuous dislocations has a significant effect on reducing the stress state of the array. This is evident in the example of the K.A. Rumiantsev Mine and the A.I. Haiovyi Mine, characterized by the same intensity of modern movements, but different the ancients.

The measured values of the components of the stress field at different depths (the Y.O. Haharin Mine) and along strike (the A.I. Haiovyi Mine) are changing [3].

In the mines of the region, measurements were carried out at different depths in the range from 550 to $950 \mathrm{~m}$. By depth of magnitude the components of the stress field increase: the values of the vertical and average horizontal component of the stress field have approximately the same gradient of change $(0.045 \mathrm{MPa} / \mathrm{m}$ and $0.040 \mathrm{MPa} / \mathrm{m}$ respectively), the gradient of the maximum horizontal component is $0.100 \mathrm{MPa} / \mathrm{m}$. It should also be noted that the stress variance is significantly different: for $\operatorname{Var}\left(\sigma_{2}\right)$ and $\operatorname{Var}\left(\sigma_{3}\right)$, they are $15.44 \mathrm{MPa}^{2}$ and $15.36 \mathrm{MPa}^{2}$, for $\operatorname{Var}\left(\sigma_{1}\right)$ respectively $127.88 \mathrm{MPa}^{2}$, which indicates a large scatter of values measured in different tectonic blocks.

Consider the results of measurements of stresses in one tectonic block and at the same depth (the field of mine named. A.I. Haiovyi, $860 \mathrm{~m}$ ). The values of the maximum and minimum horizontal components of the stress field $\sigma_{1}$ and $\sigma_{3}$ vary considerably: $\sigma_{1}$ from 32 to $63 \mathrm{MPa} ; \sigma_{3}$ from 17 to $27 \mathrm{MPa}, \sigma_{2}$ varies slightly. At some points, there is also a change in the directions of orientation of the maximum horizontal component. The measured data [3] show that within one mine field the values of maximum horizontal stresses at one depth differ. Since, according to the map of modern movements, the magnitude of $\Sigma A$ is constant within the mine field, it seems that the main influence on the tense state of the massif is paleodisturbance.

\section{Results and discussion}

The results of the studies performed show that the stress fields measured under the conditions of the mines of the Central Region are mainly due to modern movements, but the palaeological disturbance of tectonic blocks with discontinuous dislocations has a significant effect on the change in the stress state of the array (Table 2). If the stress state depends on paleo-and modern tectonic dislocation, which is caused by geodynamic processes, then it is associated with these processes.

However, it is impossible to calculate the index $K_{t}$ on unprocessed seams, therefore, it is proposed to use geological exploration data to predict the stress state of the massif, which made it possible to calculate non-dimensional indicators from the geological and structural maps: intensity of paleodislocation $C_{d}$ and rupture dislocation $C_{r}$ for individual regions [1]. 
Table 2. Characteristics of the stress-strain state of the mines of the Central Region.

\begin{tabular}{|c|c|c|c|c|c|c|}
\hline \multirow[t]{2}{*}{ Name of Mine } & \multicolumn{3}{|c|}{$\begin{array}{l}\text { Main components of } \\
\text { the stress field, MPa }\end{array}$} & \multirow{2}{*}{$\begin{array}{c}\text { Octahedral } \\
\text { stress } \sigma_{0}, \\
\mathrm{MPa}\end{array}$} & \multirow{2}{*}{$\begin{array}{l}C_{d}, \\
\text { non- } \\
\text { dim. }\end{array}$} & \multirow[t]{2}{*}{$\begin{array}{c}\sum A, \\
\mathrm{~mm} / \text { yea }\end{array}$} \\
\hline & $\sigma_{1}$ & $\sigma_{2}$ & $\sigma_{3}$ & & & \\
\hline $\begin{array}{l}\text { Yu.O. Haharin Mine, } \\
\text { horizon } 830-950 \mathrm{~m}\end{array}$ & 49.0 & 22.6 & 18.3 & 29.9 & 0.45 & 2.6 \\
\hline $\begin{array}{l}\text { K.A. Rumiantsev Mine, } \\
\text { horizon } 850-970 \mathrm{~m}\end{array}$ & 49.3 & 22.8 & 18.3 & 30.3 & 0.45 & 6.0 \\
\hline $\begin{array}{l}\text { A.I. Haiovyi Mine, } \\
\text { horizon } 860 \mathrm{~m}\end{array}$ & 49.0 & 20.8 & 19.1 & 29.6 & 0.55 & 6.6 \\
\hline
\end{tabular}

Comparison of the characteristics of the stress state in the mines of the Central Region allows us to note the following features:

- for all mines of the Central Region, the octahedral stress values at the same depth are approximately equal;

- the magnitudes and directions of the measured stresses vary with depth and extension.

To characterize the stress state of the massif, various variants of coefficients based on the developed indicators of paleodislocation intensity and modern movements are considered:

- the coefficient of geodynamicity $C_{g}$, equal to the ratio of the range of vertical movements $\Sigma A$ to the degree of paleodislocation $C_{d}$;

- the coefficient $C_{g}^{1}$ is equal to the ratio of the range of vertical movements $\Sigma A$ to the rupture dislocation $C_{r}$;

- the coefficient $C_{g}^{2}$ is equal to the ratio of the intensity of modern movements $I_{c}$ to the degree of paledislocation $C_{d}$;

- the coefficient $C_{g}^{3}$ is equal to the ratio of the differentiation of modern movements $N_{c}$ to the degree of paleodislocation $C_{d}$.

Table 3 shows the values of the geodynamic coefficients calculated for some regions.

Table 3. Parameters of geodynamic indicators of geological industrial areas of Donbas.

\begin{tabular}{|l|c|c|c|c|c|c|}
\hline Regions & $\begin{array}{c}N_{c}, \\
\text { non- } \\
\text { dim. }\end{array}$ & $\begin{array}{c}\sum A, \\
\mathrm{~mm} / \text { year }\end{array}$ & $\begin{array}{c}C_{g}, \\
\text { non- } \\
\text { dim. }\end{array}$ & $\begin{array}{c}C_{g}^{1}, \\
\text { non- } \\
\text { dim. }\end{array}$ & $\begin{array}{c}C_{g}^{2}, \\
\text { non- } \\
\text { dim. }\end{array}$ & $\begin{array}{c}C_{g}^{3}, \\
\text { non- } \\
\text { dim. }\end{array}$ \\
\hline Chervonoarmiiskyi & 4.12 & 1.26 & 4.66 & 2.13 & 1.11 & 15.20 \\
\hline Lysychanskyi & 1.00 & 0.30 & 1.20 & 0.88 & 1.20 & 16.00 \\
\hline Donetsko-Makiivskyi & 12.51 & 3.97 & 4.66 & 5.75 & 34.75 & 0.90 \\
\hline Central & 10.92 & 5.57 & 10.51 & 15.47 & 20.26 & 0.96 \\
\hline Almazno-Marivskyi & 8.58 & 3.56 & 6.59 & 5.74 & 15.90 & 0.76 \\
\hline Luhanskyi & 4.08 & 2.78 & 4.71 & 4.88 & 6.91 & 1.12 \\
\hline Krasnodonskyi & 3.91 & 4.75 & 7.78 & 8.33 & 6.42 & 1.96 \\
\hline $\begin{array}{l}\text { Chystiakovo- } \\
\text { Snizhnianskyi }\end{array}$ & 5.20 & 2.00 & 4.00 & 4.16 & 10.40 & 0.76 \\
\hline $\begin{array}{l}\text { Orikhovskyi, Bokovo- } \\
\text { Khrustalskyi }\end{array}$ & 5.75 & 4.60 & 8.84 & 8.51 & 11.06 & 1.54 \\
\hline
\end{tabular}

It is obvious that the nature of the change in geodynamic coefficients differs by region. It was shown above that geodynamic processes influence the formation of the physicomechanical properties of a massif. We compare the calculated coefficients with the 
average values of indicators characterizing the plasticity $C_{p l}$ and the relative microdisruption $C_{m d}$ of quartz grains; breaking characteristics $R$ and fracturing $L$ of coal, geophysical parameters of logging of geological exploration wells: longitudinal velocity, gamma-gamma logging (GGL), specific electrical resistance $\left(V_{p}, J_{g g}\right.$ and $\rho_{\mathrm{k}}$ respectively), reflecting mainly structural and density properties of rocks in certain geological and industrial areas of Donbas.

The correlation coefficients of the proposed geodynamic parameters with the parameters of the physical and mechanical properties of the massif are given in Table 4.

The calculated statistical criteria indicate the reliability of the calculated coefficients.

Table 4. Correlation coefficients between the indicators characterizing the stress state and the physical-mechanical properties of rock.

\begin{tabular}{|c|c|c|c|c|c|c|c|}
\hline Indices & $\begin{array}{c}C_{m d}, \\
\%\end{array}$ & $\begin{array}{c}C_{p l}, \\
\mathrm{~mm}^{-1}\end{array}$ & $\begin{array}{c}R, \\
\mathrm{~mm}^{-1}\end{array}$ & $\begin{array}{c}L, \\
\mathrm{~cm}^{-1}\end{array}$ & $\begin{array}{c}V_{p}, \\
\mathrm{~km} / \mathrm{s}\end{array}$ & $\begin{array}{c}\rho_{\mathrm{k}}, \\
\mathrm{k} \Omega \cdot \mathrm{m}\end{array}$ & $\begin{array}{c}J_{g g}, \\
\text { non-dim. }\end{array}$ \\
\hline$C_{g}^{3}$ & 0.71 & 0.79 & 0.24 & -0.61 & -0.06 & -0.06 & -0.76 \\
\hline$C_{g}^{2}$ & -0.51 & -0.31 & -0.44 & 0.29 & -0.02 & -0.17 & 0.29 \\
\hline$C_{g}^{1}$ & 0.43 & 0.88 & 0.85 & 0.06 & 0.90 & 0.91 & -0.20 \\
\hline$C_{g}$ & 0.72 & 0.54 & 0.86 & 0.03 & 0.66 & 0.67 & -0.34 \\
\hline
\end{tabular}

Rather high correlation coefficients between the indicators characterizing the stress state $C_{g}^{1}$ and the physical-mechanical properties of rocks indicate the presence of statistical relationships between them. This leads to the conclusion that the stress state as well as the physical-mechanical properties is due to geodynamic processes. Since the sum of the absolute values of the correlation coefficients between the geodynamic coefficients $C_{g}^{1}$ and the physical-mechanical properties of the massif is the largest, this indicator is the most informative and can be used to characterize the stress state of the rock mass. Based on the fact that the existing tectonic schemes and maps of modern movements allow to calculate the indices $C_{g}^{1}$, it is possible to obtain an approximate characteristic of the stress state of the studied region (mine). The directions of the axes of the main components of the stress field can be determined by the directions of the strike and the types of large-amplitude rupture dislocations bounding the section. It should be noted that earlier studies $[8,9]$ have established that a wave-like change in the stress state of the massif occurs with depth, which causes the appearance below $500 \mathrm{~m}$ of zones that are characterized by a predominance of displacement dislocations, increased fracturing, gas-bearing and gasdynamic activity. The results obtained can be used in the laying of mine workings and methane drainage borehole.

\section{Conclusions}

The stress state of the Donbas rocks in size, distribution and spatial orientation of the main components of the stress tensor within the Donbas, individual mines and horizons is heterogeneous. This variability is due to the formation of local conditions against the background of regional fields; the regional field is created by the prevailing horizontal stresses associated with geodynamic processes and the gravitational load of the overlying rocks; local field due to the mineralogical composition of rocks and paleotectonic dislocation.

Quantitatively the stress state of the region can be approximately calculated from the 
existing tectonic schemes and maps of modern movements using the coefficient $C_{g}^{1}$ is equal to the ratio of the range of vertical movements $\Sigma A$ to the rupture dislocation $C_{r}$.

\section{References}

1. Bulat, A.F., Pimonenko, L.I., Pimonenko, D.N. (2014). Otsenka perspektivnosti obektov dlya dobychi metana uglegazovyh mestorozhdeniy Donbassa. Ugol Ukrainy, 6, 41-47

2. Mineev, S.P. (2009). Svoystva gazonasyshchennogo uglya. Dnipropetrovsk: NGU

3. Kulinich, V.S., Shevelev, G.A., Egorov, S.I. (1994). Metody i sredstva opredeleniya parametrov geomehanicheskogo sostoyaniya gazonosnogo porodnogo massiva. Donetsk: TsBNTI

4. Kuzmin, Yu.O., Zhukov, V.S. (2004). Sovremennaya geodinamika i variatsii fizicheskih svoystv gornyh porod. Moskva: MGGU

5. Sherman, S.I. (2007). Sovremennaya geodinamika razlomov litosfery: novye zakonomernosti i ih veroyatnaya priroda. Fundamentalnye problemy geotektoniki. Materialy XL Tektonicheskogo soveschaniya, 2, 366-368

6. Bulin, N.L. (1971). Sovremennoe pole napryazheniy v verhnih gorizontah zemnoy kory. Geotektonika, 3, 3-15

7. Borodulin, M.I. (1976). Sistema glubinnyh razlomov po dannym glubinnogo seysmicheskogo zondirovaniya. Geologicheskiy zhurnal, 5, 88-96

8. Lukinov, V.V., Pimonenko, D.N. (2013). Zakonomernosti raspredeleniya razryvnoy maloamplitudnoy narushennosti v uglenosnyh otlozheniyah Donetskogo basseyna. Izvestiya vysshih uchebnyh zavedeniy. Gornyy zhurnal. Ekaterinburg, 6, 76-84

9. Mineev, S.P., Prusova, A.A., Kornilov, M.G. (2007). Aktivatsiya desorbtsii metana $v$ ugolnyh plastah. Dnipropetrovsk: Veber 